\title{
Effect of erythrosine and phloxine from xanthene food dyes on oxidative stress in Chinese hamster ovary cells
}

\author{
Omca DEMIRKOL ${ }^{1 *}$ (D), Özlem Aktürk GÜMÜŞAY², İnci CERIT¹ ${ }^{1}$ (D)
}

\begin{abstract}
Objective of this study was to investigate the changes of oxidative stress parameters in Chinese hamster ovary (CHO) cells exposed to xanthene food dyes (erythrosine and phloxine), commonly-used azo dyes in the food industry. For this purpose, glutathione (GSH) and malondialdehyde (MDA) levels, glutathione peroxidase (GPx) and catalase (CAT) activity measurements of $\mathrm{CHO}$ cells treated with erythrosin $(50 \mu \mathrm{M})$ and phloxine $(40 \mu \mathrm{M})$ were compared with the control group. There was no significant difference between MDA levels in CHO cells exposed to both dyes and control group ( $p>0.05)$, however GSH levels significantly decreased with dye addition $(\mathrm{p} \leq 0.05)$. An increase in GPx activity of the CHO cells exposed to phloxin was observed ( $\mathrm{p} \leq 0.05)$. However, there was no change in $\mathrm{GP}_{\mathrm{x}}$ activity of erythrosin-exposed CHO cells $(\mathrm{p}>0.05)$. In terms of CAT activity, difference between the dye-added cells and the control group was not observed. Consequently, decrease in level of GSH, which one of major antioxidant components in the cell, suggests that erythrosine and phloxine can have a toxic effect.
\end{abstract}

Keywords: Chinese hamster ovary ( $\mathrm{CHO}$ ) cells; erythrosine; oxidative stress; phloxine; xanthene food dye.

Practical Application: Dyes are a class of food additives which are added to food for providing attractive color. Erythrosine and phloxine are halogenated xanthene dyes and they are often found in the beverages, sweets, confectionery and cake decorating materials. The main emphasis of this research is to focus on the effect of erythrosine and phloxine from xanthene food dyes on oxidative stress in Chinese hamster ovary cells. We believe that this study will provide important contributions to the studies related to the use of food dyes.

\section{Introduction}

Food color is an important factor that influence customers' preferences. However, food process operations can be negatively affect the food color. Food dyes are generally added into processed food products to enhance the color quality. Compared with natural dyes, synthetic food dyes are more preferred in food industry. Because synthetic food dyes have high stability to $\mathrm{pH}$, oxygen and light. Another advantage of synthetic food dyes can be lower production costs and microbiological contamination (Downham \& Collins, 2000; Gomes et al., 2013; Lok et al., 2011).

Colorful foods especially attract children's attention. Feingold (1976) reported that artificial food dyes affect the nervous system involvement. In addition to this, consumption of foods added artificial colors may be caused to Hyperkinesis and learning disabilities in children. Researchers shown that synthetic food dyes developed the hyperactivity in 3 and 8/9 year old children (McCann et al., 2007; Arnold et al., 2012).

Erythrosine and phloxine are halogenated xanthene dyes. They are often found in the beverages, sweets, confectionery and cake decorating materials. Halogenated xanthene dyes were known as a photosensitizer and can be electronically induced by irradiation when light is at correct wavelength. They are caused to production reactive oxygen species (especially singlet oxygen). These reactive oxygen species are known to effect the photomodification of some molecules in cells, especially DNA, lipid and enzymes (Girotti, 2001; Wang et al., 2006; Epelde-Elezcano et al., 2016).

Lipid oxidation including photooxidation has an important adverse effect on food quality. As photooxidation occurs quicker, free radical oxidation increases. Xanthene dyes can be increase oxidative damage in food because they are known as strong photosensitizer (Kajimoto et al., 1994; Pan et al., 2005a).

Pan et al. (2005b) reported that increase in the total hydroperoxide content of a sea product (surumi) with added phloxine and erythrosine. Mizutani (2009) also shown that superoxide anions, generating on xanthene dyes by light irradiation, were caused to inhibition of some metabolic enzymes in human microsomes. Another study about xanthene dyes suggests that erythrosine may reduce motor activity of male rats (Dalal \& Poddar, 2009). Abdel Aziz et al. (1997) reported that erythrosine in the used doses has a potential toxic effect on spermatogenesis in mice, it may affect its reproductive performance.

Studies about phloxine indicated that phloxine has phototoxic effect and this can be damaged the cellular membran and DNA. These results indicate that consideration is authorized about the usage dose of phloxine in food a cosmetic industry (Valenzeno \& Pooler, 1982; Inbaraj et al., 2005; Qi et al., 2012). 
In this study, we have investigated the changes of oxidative stress parameters in $\mathrm{CHO}$ cells exposed to erythrosine and phloxine dyes. In accordance with this purpose, levels of GSH and MDA, GPx and CAT activity of CHO cells treated with erythrosin $(50 \mu \mathrm{M})$ and phloxine $(40 \mu \mathrm{M})$ were compared with the control group.

\section{Materials and methods}

Solvents for chromatographic analysis were obtained from Fisher Scientific (Fair Lawn, NJ, USA). Other all chemicals were supplied from Sigma-Aldrich (St. Louis, MO, USA).

\subsection{Preparation of $\mathrm{CHO}$ cells}

$\mathrm{CHO} \mathrm{K} 1$ cells were purchased from ATCC. Before the analysis, they were grown in a special culture medium. Ten percent fetal bovine serum was used as medium supplement. Penicillin and streptomycin were combined with medium, $100 \mathrm{U} / \mathrm{mL}$ and $100 \mu \mathrm{g} / \mathrm{mL}$, respectively. The cells were incubated at $37^{\circ} \mathrm{C}$ and incubator was adjusted to $95 \% \mathrm{O}_{2}$ and $5 \% \mathrm{CO}_{2}$.

\subsection{Oxidative stress tests}

CHO cells (contain $\sim 5 \times 10^{6}$ cells per mL, exponentially growing) were formed as separate culture. After all-night incubation, media was replace with the fresh one which included changeable concentration of food dyes. Concentrations of food dyes were decided based on study about toxicity of xanthene food dyes by inhibition of human drug-metabolizing enzymes of by Mizutani (2009). Mizutani (2009) shown that erythrosine and phloxine caused specific inhibition of UGT1A6 at $50 \mu \mathrm{M}$ and $40 \mu \mathrm{M}$ concentrations, respectively. Superoxide anions arise from singlet oxygen were effective in this inhibition.

The food colors-exposed groups and control group were incubated for $24 \mathrm{~h}$. After incubation time, the culture media was separated and cells cleansed. The cells trypsinized, and homogenized for further experiments. Generally, results in oxidative stress studies are discussed together with minimum of three separate experiments. Thus, four separate experiments (GSH, MDA levels, GPx and CAT activity) were performed in this study.

\subsection{Determination of GSH}

Reverse phase-HPLC was used for measurement of GSH level in the cells according to the previous study by Ridnour et al. (1999). The HPLC system properties and experimental procedure were mentioned in our previous work (Demirkol et al., 2012).

\subsection{Determination of $M D A$}

Determination of MDA levels of cells was carried out with HPLC according to method of Draper et al. (1993). One hundred $\mu \mathrm{L}$ butylated hydroxytoluene (500 ppm, in methanol), $550 \mu \mathrm{L}$ tricholoroacetic acid (5\%, in methanol) and $350 \mu \mathrm{L}$ cell homogenates were added in test tubes. Then test tubes were placed in boiling water bath. After thirty minutes, they were cooled and centrifuged. Supernatant was obtained and mixed with saturated thiobarbituric acid (1:1). The mixture was again placed in boiling water bath for $30 \mathrm{~min}$. And then they were again cooled. For seperation of phase, the mixture $(500 \mu \mathrm{L})$ and $\mathrm{n}$-butanol $(1 \mathrm{~mL})$ were added in new centrifuge tube and centrifuged. Before injection to HPLC system (consisting of binary pump, injection valve and fluorescence detector) (Shimadzu, US), $0.45 \mu \mathrm{m}$ filters were used. HPLC was equipped with a C18 column (100 mm $\times 4.6 \mathrm{~mm}$ i.d.) (Astec, Bellefonte, PA). The best separation was achieved by using a mobile phase consisting of $69.4 \%$ sodium phosphate buffer, $30 \%$ acetonitrile, and $0.6 \%$ tetrahydrofuran. The wavelengts for $\lambda_{\mathrm{ex}}$ and $\lambda_{\mathrm{em}}$ were 515 and $550 \mathrm{~nm}$, respectively. Malondialdehyde bis (dimethyl acetal) was used as a standart for calibration.

\subsection{CAT activity measurement}

CAT activity measurement was performed with spectrophotometer (Aebi, 1984). Experimental details were mentioned in our previous work (Demirkol et al., 2012).

\subsection{GPx activity measurement}

A test kit (OxisResearch) was used for determination of GPx activity. This experimental procedure is known as indirect measurement of cellular GPx activity. GSSG, which known as the oxidized form of GSH, generated with reduction of an organic peroxide by GPx enzyme and is recycled to reduced form by glutathione reductase (GR). To assay GPx, a cell sample is mixed with a solution including NADPH, GSSG and GR. Decline in absorbance (for three min and at $340 \mathrm{~nm}$ ) is denoted that oxidation of $\mathrm{NADPH}$ to $\mathrm{NADP}^{+}$. In this procedure, tert-butyl hydroperoxide is used as the working substrate for initiation of enzyme reaction.

\subsection{Determination of protein}

Protein level determination is performed according to the method described by Bradford (1976). Coomassie Blue dye (diluted with water, 1:5 (v/v)) and cell homogenate were mixed in a test tube, and then absorbance value was spectrophotometrically measured at $595 \mathrm{~nm}$ wavelength. Bovine serum albumin was selected as the standard for calibration.

\subsection{Statistical analysis}

Analysis results were expressed as mean values with standard deviations. The one-way ANOVA and Student-Newman-Keuls multiple comparison tests were performed with a significance level of $\mathrm{p}<0.05$.

\section{Results}

\subsection{Introcellular GSH level}

HPLC results of GSH level after derivatising samples with NPM were expressed as nM GSH per $1 \mathrm{mg}$ of protein. CHO cells treated with erythrosine $(50 \mu \mathrm{M})$ and phloxine $(40 \mu \mathrm{M})$ were compared with the control group (Figure 1). GSH levels for erythrosine-exposed and phloxine-exposed $\mathrm{CHO}$ cells were determined as 52.35 and $16.50 \mathrm{nM} \mathrm{GSH} / \mathrm{mg}$, respectively. 


\subsection{MDA measurements}

In this study, MDA levels in control, erythrosine and phloxine exposed $\mathrm{CHO}$ cells were determined as $14.59,14.90$ and $14.18 \mathrm{~nm} / 100 \mathrm{mg}$ protein, respectively. There was no significant difference in MDA levels of CHO cells exposed to both dyes and control group ( $\mathrm{p}>0.05)$ (Figure 2).

\subsection{CAT activities}

CAT activities of control, erythrosine and phloxine exposed $\mathrm{CHO}$ cells were found as $0.032,0.020$ and $0,025 \mathrm{U} / \mathrm{mg}$ protein, respectively. A significant difference was not found in CAT

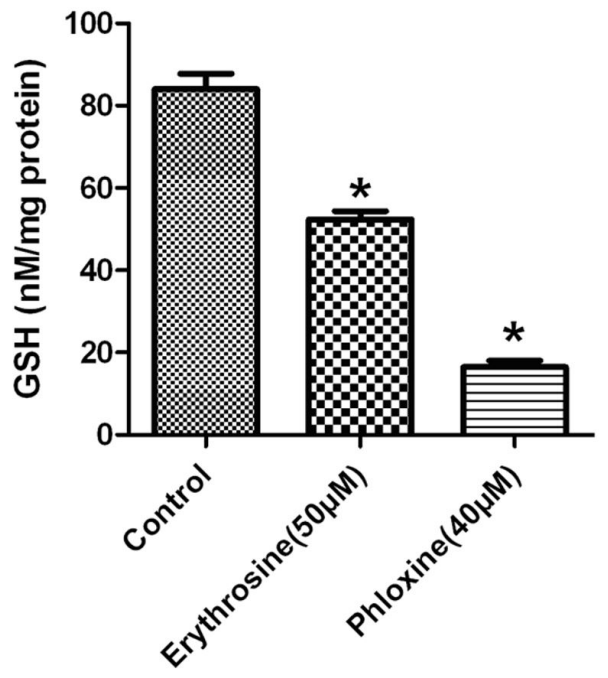

Figure 1. Effects of Erythrosine $(50 \mu \mathrm{M})$ and Phloxine $(40 \mu \mathrm{M})$ on the GSH level in CHO cells. Cells were treated with dyes for $24 \mathrm{~h}$. Experiments were carried out in triplicate, and the values were expressed as mean $\pm \mathrm{SD}$. Asterisks indicate the significant difference from the control with $\mathrm{p}<0.05$.

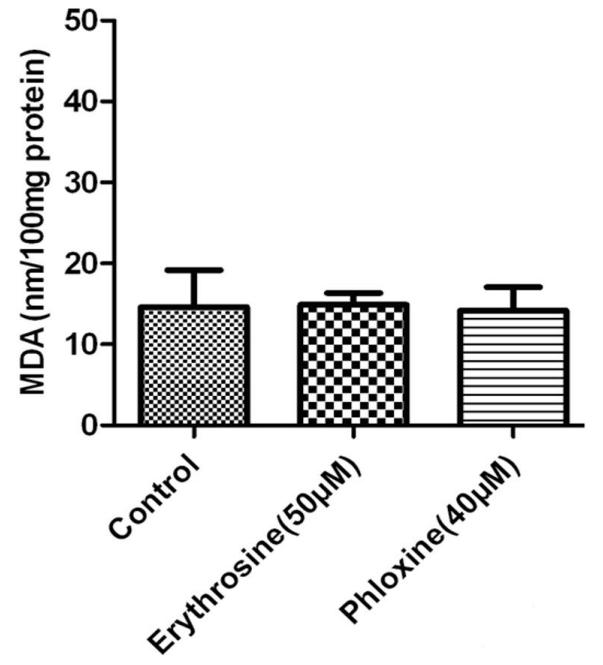

Figure 2. Effects of Erythrosine $(50 \mu \mathrm{M})$ and Phloxine $(40 \mu \mathrm{M})$ on the levels of MDA in $\mathrm{CHO}$ cells. Cells were retreated with dyes for $24 \mathrm{~h}$. Experiments were carried out in triplicate, and the values were expressed as mean $\pm \mathrm{SD}$. activity results, after erythrosine and phloxine were added to in $\mathrm{CHO}$ cells $(\mathrm{p}>0.05)$ (Figure 3$)$.

\subsection{GPx activities}

GPx activities of control, erythrosine and phloxine exposed CHO cells were determined as $4.733,3.551$ ve $10.964 \mathrm{mU} / \mathrm{mg}$ protein. There was no statistically significant difference in the GPx activities between control group and erythrosine-treated CHO cells ( $p>0.05$ ), while GPx activity increased in phloxine-exposed $\mathrm{CHO}$ cells compared to control group $(\mathrm{p}<0.05)$ (Figure 4).

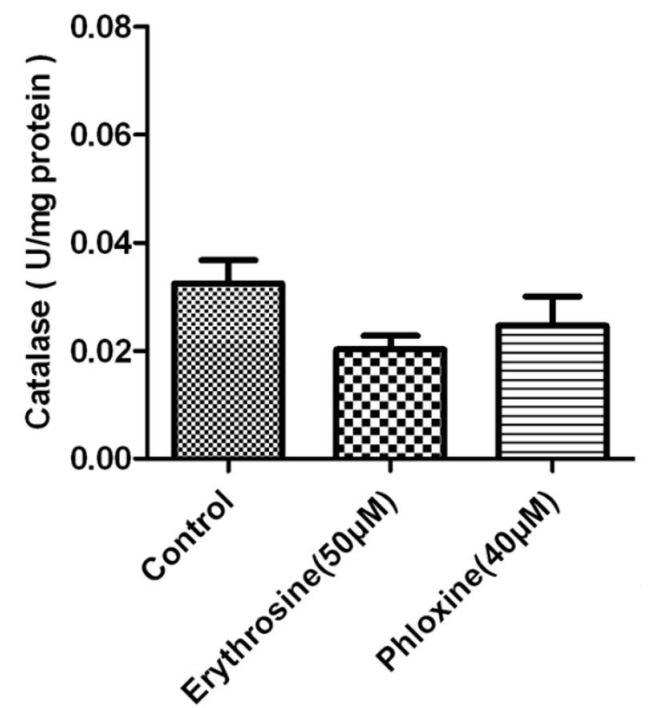

Figure 3. Effects of Erythrosine $(50 \mu \mathrm{M})$ and Phloxine $(40 \mu \mathrm{M})$ on the CAT activity in CHO cells. Cells were retreated with dyes for $24 \mathrm{~h}$. Experiments were carried out in triplicate, and the values were expressed as mean $\pm \mathrm{SD}$.

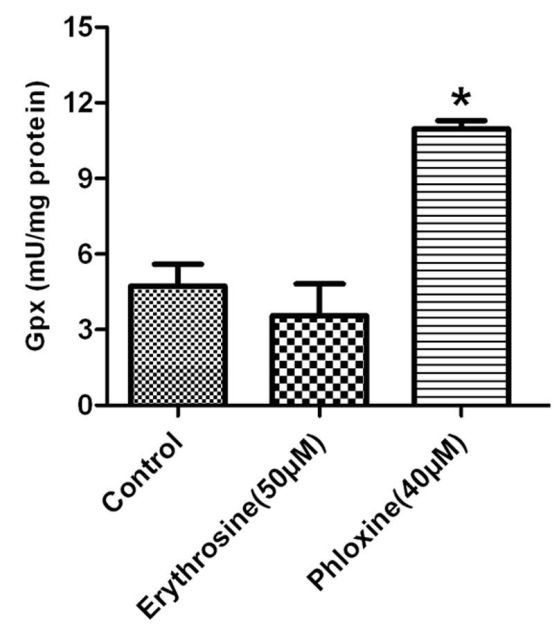

Figure 4. Effects of Erythrosine $(50 \mu \mathrm{M})$ and Phloxine $(40 \mu \mathrm{M})$ on the GPx activity in CHO cells. Cells were retreated with dyes for $24 \mathrm{~h}$. Experiments were performed in triplicate, and the values were expressed as mean \pm SD. Asterisks indicate the significant difference from the control with $\mathrm{p}<0.05$. 


\section{Discussion}

In the present study, oxidative stress parameters (MDA, GSH, GPx and CAT activity levels) were determined in the $\mathrm{CHO}$ cells treated with erythrosine and phloxine. HPLC results indicated that GSH level significantly decreased with addition of erythrosine and phloxine $(\mathrm{p}<0.05)$. This result suggested that erythrosine and phloxine caused to production reactive oxygen species. Xanthene dyes causes the formation of variable amount of ${ }^{1} \mathrm{O}_{2}$ depending on the number of halogen substituents, atomic mass of the halogens and the strength of the light (Wang et al., 2006). ${ }^{1} \mathrm{O}$, which highly reactive molecule, tends to generation of peroxide products (Furumiya \& Mizutani, 2008). This causes an increase in oxidative stress. GSH is a low molecular weight thiol and very active antioxidant. It acts as a substrate against to oxidant products to decrease the oxidative stress in the media (Kleinman \& Richie, 2000). Therefore, this reduction in the amount of GSH is expected result. Qi et al. (2014) reported that GSH levels of human acute promyelocytic leukemia HL-60 cells exposed with 100 and $200 \mu \mathrm{M}$ phloxine were lower than control group. Mutoh et al. (2005) also stated that GSH levels in the phloxine-exposed yeast (Schizosaccharomyces pombe) cell decreased.

DNA single strain breaks were detected in erythrosine-exposed HepG 2 cells according to results of another study about xanthene dyes. It has long been known that increment in oxidative stress caused by various causes such as halogenated xanthene dyes leads to DNA damage (Chequer et al., 2012, 2017).

In terms of oxidative damage, MDA is known as an indicator for lipid peroxidation. In our study, dye concentrations were not adequate to effect the MDA levels of cell samples. In other respects, it can be deduced that antioxidant defense system can overcome oxidative stress caused by dyes and preserve the cells from the lipid peroxidation. This is a respected result for oxidative stress studies. There is not any researches about investigation of effect of xanthene dyes on level of MDA, however Demirkol et al. (2012) stated that MDA levels increased when $\mathrm{CHO}$ cells were treated with tartrazine and new coccin dyes.

CAT, which is used as the parameter for oxidative stress, play as a catalyst in the decomposition of hydrogen peroxide to molecular oxygen and water (Pan \& Du, 2017; Urso \& Clarkson, 2003). In this study, there was no important change in CAT activity. This may be caused by the concentration of dyes used. Similarly, Neal et al. (1997) observed no change in CAT activity with increase in oxidative stress in $\mathrm{CHO}$ cells.

GPx is known as an enzyme to catalyze the reduction of $\mathrm{H}_{2} \mathrm{O}_{2}$ or organic hydroperoxides, using $\mathrm{GSH}$ as reductant (Maiorino et al., 1995). Although GPx activity were not change with adding of erythrosine, a significant reduction in GSH levels was observed. This result suggested that GSH may be react with ROS non-enzymatically. On the one hand, GSH detoxified ROS, on the other hand it was oxidized to GSSG by the reaction catalyzed by GPx. In this case, an increase in GPx activity may be occur to overcome the increased oxidative stress caused by xanthene dyes and decrease the $\mathrm{H}_{2} \mathrm{O}_{2}$. However, GSH may be depleted with increase of oxidative stress and GPx activity may decrease in the media. As a result, non-reduction $\mathrm{H}_{2} \mathrm{O}_{2}$ can cause damage to the cell. Antioxidant enzyme activities relies on the character of oxidant and continuance time.

\section{Conclusion}

Food xanthene dyes like erythrosine and phloxine can affect adversely the health when used in high doses. Because xanthene dyes promote ROS formation with increase in the oxidative stress and this may result in cell damage. In our study, oxidative stress increased in dye-exposed $\mathrm{CHO}$ cells. It is required to create consumer awareness regarding the harm effects of food dyes such as erythrosine and phloxine and note the name and concentration of each dye added to food. We believe that studies about food dyes will contribute to more extensive assessments on the use of food dyes.

\section{Acknowledgements}

Authors would like to thank Dr. Nuran Ercal and Dr. Xinsheng Zhang for their valuable contributions.

\section{References}

Abdel Aziz, A. H., Shouman, S. A., Attia, A. S., \& Saad, S. F.. . (1997). A study on the reproductive toxicity of erythrosine in male mice. Pharmacological Research, 35(5), 457-462. http://dx.doi.org/10.1006/ phrs.1997.0158. PMid:9299211.

Aebi, H. (1984). Catalase in vitro. Methods in Enzymology, 105, 121-126. http://dx.doi.org/10.1016/S0076-6879(84)05016-3. PMid:6727660.

Arnold, L. E., Lofthouse, N., \& Hurt, E. (2012). Artificial food colors and attention-deficit/hyperactivity symptoms: conclusions to dye for. Neurotherapeutics, 9(3), 599-609. http://dx.doi.org/10.1007/ s13311-012-0133-x. PMid:22864801.

Bradford, M. M. (1976). A rapid and sensitive method for the quantitation of microgram quantities of protein utilizing the principle of proteindye binding. Analytical Biochemistry, 72(1-2), 248-254. http://dx.doi. org/10.1016/0003-2697(76)90527-3. PMid:942051.

Chequer, F. M. D., Venancio, V. P., Bianchi, M. D. L. P., \& Antunes, L. M. G. (2012). Genotoxic and mutagenic effects of erythrosine B, a xanthene food dye, on HepG2 cells. Food and Chemical Toxicology, 50(10), 3447-3451. http://dx.doi.org/10.1016/j.fct.2012.07.042. PMid:22847138.

Chequer, F. M., Venancio, V. P., Almeida, M. R., Aissa, A. F., Bianchi, M. L. P., \& Antunes, L. M. (2017). Erythrosine B and quinoline yellow dyes regulate DNA repair gene expression in human HepG2 cells. Toxicology and Industrial Health, 33(10), 765-774. http://dx.doi. org/10.1177/0748233717715186. PMid:28893156.

Dalal, A., \& Poddar, M. K. (2009). Short-term erythrosine B-induced inhibition of the brain regional serotonergic activity suppresses motor activity (exploratory behavior) of young adult mammals. Pharmacology, Biochemistry, and Behavior, 92(4), 574-582. http:// dx.doi.org/10.1016/j.pbb.2009.02.010. PMid:19264092.

Demirkol, O., Zhang, X., \& Ercal, N. (2012). Oxidative effects of Tartrazine (CAS No. 1934-21-0) and New Coccin (CAS No. 261182-7) azo dyes on CHO cells. Journal für Verbraucherschutz und Lebensmittelsicherheit, 7(3), 229-236. http://dx.doi.org/10.1007/ s00003-012-0782-z.

Downham, A., \& Collins, P. (2000). Colouring our foods in the last and next millennium. International Journal of Food Science \& Technology, 35(1), 5-22. http://dx.doi.org/10.1046/j.1365-2621.2000.00373.x.

Draper, H. H., Squires, E. J., Mahmoodi, H., Wu, J., Agarwal, S., \& Hadley, M. (1993). A comparative evaluation of thiobarbituric acid methods for the determination of malondialdehyde in biological 
materials. Free Radical Biology \& Medicine, 15(4), 353-363. http:// dx.doi.org/10.1016/0891-5849(93)90035-S. PMid:8225017.

Epelde-Elezcano, N., Martínez-Martínez, V., Pena-Cabrera, E., GómezDurán, C. F., Arbeloa, I. L., \& Lacombe, S. (2016). Modulation of singlet oxygen generation in halogenated BODIPY dyes by substitution at their meso position: towards a solvent-independent standard in the vis region. RSC Advances, 6(48), 41991-41998. http://dx.doi. org/10.1039/C6RA05820E.

Feingold, B. F. (1976). Hyperkinesis and learning disabilities linked to the ingestion of artificial food colors and flavors. Journal of Learning Disabilities, 9(9), 551-559. http://dx.doi.org/10.1177/002221947600900902.

Furumiya, K., \& Mizutani, T. (2008). Inhibition of human CYP3A4, UGT1A6, and P-glycoprotein with halogenated xanthene food dyes and prevention by superoxide dismutase. Journal of Toxicology and Environmental Health. Part A., 71(19), 1307-1313. http://dx.doi. org/10.1080/15287390802240751. PMid:18686201.

Girotti, A. W. (2001). Photosensitized oxidation of membrane lipids: reaction pathways, cytotoxic effects, and cytoprotective mechanisms. Journal of Photochemistry and Photobiology B, Biology, 63(1-3), 103-113. http://dx.doi.org/10.1016/S1011-1344(01)00207-X. PMid:11684457.

Gomes, K. M. S., Oliveira, M. V. G. A. D., Carvalho, F. R. D. S., Menezes, C. C., \& Peron, A. P. (2013). Citotoxicity of food dyes sunset yellow (E-110), bordeaux red (E-123), and tatrazine yellow (E-102) on Allium cepa L. root meristematic cells. Food Science and Technology, 33(1), 218-223. http://dx.doi.org/10.1590/S0101-20612013005000012.

Inbaraj, J. J., Kukielczak, B. M., \& Chignell, C. F. (2005). Phioxine B phototoxicity: a mechanistic study using $\mathrm{HaCaT}$ keratinocytes. Photochemistry and Photobiology, 81(1), 81-88. http://dx.doi. org/10.1562/2003-11-04-RA-002.1. PMid:15473832.

Kajimoto, G., Yamaguchi, M., Kasutani, S., Yoshida, H., \& Shibahara, A. (1994). Influence of synthetic food colorants on oxidative deterioration of oil. Nippon Shokuhin Kogyo Gakkaishi, 41(11), 793-796. http:// dx.doi.org/10.3136/nskkk1962.41.793.

Kleinman, W. A., \& Richie, J. P. Jr. (2000). Status of glutathione and other thiols and disulfides in human plasma. Biochemical Pharmacology, 60(1), 19-29. http://dx.doi.org/10.1016/S0006-2952(00)00293-8. PMid:10807941.

Lok, K. Y. W., Chung, Y. W., Benzie, I. F. F., \& Woo, J. (2011). Synthetic colourings of some snack foods consumed by primary school children aged 8-9 years in Hong Kong. Food Additives and Contaminants: Part B, 4(3), 162-167. http://dx.doi.org/10.1080/19393210.2011.5 85246. PMid:24786002.

Maiorino, F. M., Brigelius-Flohé, R., Aumann, K. D., Roveri, A., Schomburg, D., \& Flohé, L. (1995). [5] Diversity of glutathione peroxidases. Methods in Enzymology, 252, 38-53. http://dx.doi. org/10.1016/0076-6879(95)52007-4. PMid:7476373.

McCann, D., Barrett, A., Cooper, A., Crumpler, D., Dalen, L., Grimshaw, K., Kitchin, E., Lok, K., Porteous, L., Prince, E., Sonuga-Barke, E., Warner, J. O., \& Stevenson, J. (2007). Food additives and hyperactive behaviour in 3-year-old and 8/9-year-old children in the community: a randomised, double-blinded, placebo-controlled trial. Lancet, 370(9598), 1560-1567. http://dx.doi.org/10.1016/ S0140-6736(07)61306-3. PMid:17825405.
Mizutani, T. (2009). Toxicity of xanthene food dyes by inhibition of human drug-metabolizing enzymes in a noncompetitive manner. Journal of Environmental and Public Health, 2009, 953952. PMid:20041016.

Mutoh, N., Kawabata, M., Nakagawa, C. W., \& Kitajima, S. (2005). Prooxidant action of phloxine B on fission yeast Schizosaccharomyces pombe. Yeast, 22(2), 91-97. http://dx.doi.org/10.1002/yea.1196. PMid:15645504.

Neal, R., Yang, P., Fiechtl, J., Yildiz, D., Gurer, H., \& Ercal, N. (1997). Pro-oxidant effects of $\delta$-aminolevulinic acid ( $\delta$-ALA) on Chinese hamster ovary (CHO) cells. Toxicology Letters, 91(3), 169-178. http://dx.doi.org/10.1016/S0378-4274(97)03887-3. PMid:9217237.

Pan, C., \& Du, X. (2017). A study on the effects of the best combination of copper, zinc, iron, and manganese on the relationship of lettuce resistance to Botrytis cinerea and its antioxidant system. Emirates Journal of Food and Agriculture, 29(5), 330-338. http://dx.doi. org/10.9755/ejfa.2016-07-840.

Pan, X., Ushio, H., \& Ohshima, T. (2005a). Effects of molecular configurations of food colorants on their efficacies as photosensitizers in lipid oxidation. Food Chemistry, 92(1), 37-44. http://dx.doi. org/10.1016/j.foodchem.2004.07.017.

Pan, X., Ushio, H., \& Ohshima, T. (2005b). Effects of food colorants on photooxidation of lipids added to Alaska pollack Theragra chalcogramma surimi. Fisheries Science, 71(2), 397-404. http:// dx.doi.org/10.1111/j.1444-2906.2005.00977.x.

Qi, H., Takano, H., Kato, Y., Wu, Q., Ogata, C., Zhu, B., Murata, Y., \& Nakamura, Y. (2012). Erratum: hydogen peroxide-dependent photocytotoxicity by phloxine $\mathrm{B}$, a xanthene-type food colorant. Biochimica et Biophysica Acta-General Subjects, 1820(7), 1020. http:// dx.doi.org/10.1016/j.bbagen.2012.04.012.

Qi, H., Wu, Q., Abe, N., Saiki, S., Zhu, B., Murata, Y., \& Nakamura, Y. (2014). Ascorbic acid synergistically potentiates phloxine b-induced photocytotoxicity in human acute promyelocytic leukemia cells. Journal of Biochemical and Molecular Toxicology, 28(4), 167-173. http://dx.doi.org/10.1002/jbt.21549. PMid:24488945.

Ridnour, L. A., Winters, R. A., Ercal, N., \& Spitz, D. R. (1999). Measurement of glutathione, glutathione disulfide, and other thiols in mammalian cell and tissue homogenates using high-performance liquid chromatography separation of $\mathrm{N}$-(1-pyrenyl) maleimide derivatives. Methods in Enzymology, 299, 258-267. http://dx.doi. org/10.1016/S0076-6879(99)99025-0. PMid:9916204.

Urso, M. L., \& Clarkson, P. M. (2003). Oxidative stress, exercise, and antioxidant supplementation. Toxicology, 189(1-2), 41-54. http:// dx.doi.org/10.1016/S0300-483X(03)00151-3. PMid:12821281.

Valenzeno, D. P., \& Pooler, J. P. (1982). Cell membrane photomodification: relative effectiveness of halogenated fluoresceins for photohemolysis. Photochemistry and Photobiology, 35(3), 343-350. http://dx.doi. org/10.1111/j.1751-1097.1982.tb02572.x. PMid:7063550.

Wang, H., Lu, L., Zhu, S., Li, Y., \& Cai, W. (2006). The phototoxicity of xanthene derivatives against Escherichia coli, Staphylococcus aureus, and Saccharomyces cerevisiae. Current Microbiology, 52(1), 1-5. http://dx.doi.org/10.1007/s00284-005-0040-z. PMid:16392007. 